\section{INTERNATIONAL UNION OF THEORETICAL AND APPLIED MECHANICS}

\begin{abstract}
A
T the Sixth International Congress for Applied Mechanics, held at the Sorbonne in Paris, during September 22-28, 1946, the International Congress Committee, under the sponsorship of which these congresses are organised, decided to create a more permanent organisation, in order to provide the possibility of carrying out activities in the interval between the congresses and of entering into cooperation with other international scientific bodies. This permanent organisation adopted the name of "The International Union of Theoretical and Applied Mechanics". In agreement with the policy followed with respect to the international congresses for applied mechanics, the structure of the new Union thus far has been kept as simple as possible; a council has been elected, consisting at present of thirty members, and a secretary has been nominated for carrying out correspondence. The Council is the executive body of the Union; its members are persons actually engaged in scientific work (theoretical or experimental) in mechanics or in related sciences. The number of members of the same nationality must not in general exceed four ; in certain cases a few extra members can form part of the Council, without being representatives of a particular country.

It is hoped that national organisations concerned with scientific work in applied mechanics and already in existence in various countries may be willing to enter into relationship with the International Union. The statutes of the latter have therefore been so framed that it will be possible to admit national organisations (or a national union of such, if there are more than one in the same country) as adhering organisations of the International Union. Any such national organisation (or union) can apply to have a representative on the Council. Organisations interested in co-operation with the International Union are invited to communicate with the representatives for their country.
\end{abstract}

Now that the draft statutes have obtained the required number of votes, the International Union is formally constituted. It will seek admission as an organisation adhering to the International Council of Scientific Unions.

Members of Council are at present: (Belgium) : L. Baes (Brussels), F. H. van den Dungen (Brussels); (Bulgaria) : K. Popoff (Sofia); (China) : P. Y. Chou (Peiping), Y. H. Ku (Shanghai); (Denmark): J. Nielsen (Copenhagen) ; (France) : A. Caquot (Paris), J. Pérès (Paris), H. Villat (Paris); (Great Britain) : S. Goldstein (Manchester), R. V. Southwell (London), G. I. Taylor (Cambridge); (Netherlands) : C. B. Biezeno (Delft), J. M. Burgers (Delft), C. Koning (Amsterdam); (Norway): J. Solberg (Oslo); (Poland): M. T. Huber (Gdańsk-Wrzeszcz); (Sweden): W. Weibull (Bofors); (Switzerland): J. Ackeret (Zurich), H. Favre (Zurich) ; (Turkey) : Kerim Erim (Istanbul); (United States): H. L. Dryden (Washington, D.C.), J. C. Hunsaker (Cambridge, Mass.), Th. von Kármán (Pasadena, Cal.), S. P. Timoshenko (Palo Alto, Cal.); (U.S.S.R.) : S. A. Christianovitch (Moscow), A. N. Kolmogoroff (Moscow), E. L. Nicolai (Leningrad). Extra members are: R. von Mises (Cambridge, Mass., U.S.A.); H. U. Sverdrup (La Jolla, Cal., U.S.A.).
The secretary for the present period is Prof. J. M. Burgers, van Houtenstraat 1, Delft, Holland.

It has been decided to accept the invitation of the Imperial College of Science and Technology, South Kensington, London, S.W.7, to hold the seventh International Congress for Applied Mechanics in its buildings during September 5-12, 1948.

\section{THE EGYPTIAN ACADEMY OF SCIENCES}

$T$ HE number of scientific workers in Egypt has increased considerably since the foundation of the Faculty of Science of the Fouad I University at Cairo in 1925. This has been accompanied by the development of a number of societies dealing with various branches of science, among which special mention may be made of the Société Entomologique d'Egypte, with its fine series of Bulletins and Mémoires dating from 1907. There has arisen also a demand for some institution where scientific specialists could meet and exchange ideas, for the famous Institut d'Egypte, founded by Napoleon, covers too wide a range of interests to meet these requirements. Accordingly, a group of nine Egyptians representing different branches of science met together in 1944 and founded an Egyptian Academy of Sciences, with Prof. Mohamed Khalil Bey as its secretary. The main objects of the new Academy are to stimulate a wider interest in science in general, and lead to more cooperation between men of science and a better coordination of their efforts.

The first volume of the Proceedings for 1945, published in 1946, has just been received, and comprises six articles dealing with biological subjects. All are written in English, but full abstracts in Arabic are included.

The first article, by the editor, Prof. K. Mansour, is devoted to an account of the Zooxanthellæ, and the food and feeding habits of the Tridacnidæ, in which the author attributes the large size reached by these lamellibranchs to their efficient feeding mechanism, and capacity of sieving huge quantities of water. The following article by Dr. J. J. Mansour-Bek deals with the digestive enzymes of Tridacna elongata and Pinctada vulgaris. In both papers the views of Prof. C. M. Yonge and others, as to the importance of intra-cellular digestion in these lamellibranchs, are strongly criticized. Prof. Y. S. Sabet describes the reaction of Citrus mycorrhiza to manurial treatment, and $\mathrm{Z}$. Ahmed the effect of some environmental conditions on the growth and alkaloidal content of Hyoscyamus muticus. The nervous control of melanophores in the Egyptian chameleon is the subject of an interesting communication by Dr. A. M. Farghaly, and finally Dr. H. Said discusses the reaction of cotton, beans and other plants to colchicine treatment.

The difficulties attending publication in a foreign language have resulted in an unduly large number of printer's errors, but these do not affect the general standard of the Proceedings. Men of science in other countries will welcome the appearance of this publication and wish the new Academy every success. The Proceedings can be obtained either by exchange of corresponding publications, or by subseription (one Egyptian pound per annum). Communications should be addressed to the Hon. Secretary, Dar el Hikma, 42 Kasr Aini Street, Cairo, Egypt. E. HrNdie 